\title{
Diagnosa, Analisis dan Identifikasi Parasit yang Menyerang Ikan Nila (Oreochromis Niloticus) Pada Kawasan Budidaya Ikan Di Subak "Baru" Tabanan
}

\author{
I Kadek Adi Wirawan, Sang Ayu Made Putri Suryani, I Wayan Arya \\ Program Studi Manajemen Sumber Daya Perairan, Fakultas Pertanian, Universitas Warmadewa \\ Email : Adiwirawan151@yahoo.com
}

\begin{abstract}
Fish cultivation business is one of the very promising business with the increasingly cheap demand of fishery products in the community. So is the case with the cultivation of Tilapia fish. Aquaculture is not spared from various obstacles and problems that often hamper fish farming is the occurrence of disease attacks. Tilapia fish Who was attacked The disease starts with by showing signs of behavioral changes. In addition to the behavior, tilapia also experience a change in color that looks very clear difference compared to fish that are still healthy. Calculation of condition factors, from the three sampling sites average fish is in poor condition indicating that most of fish in pond cultivation have decreased condition that reach $60-90 \%$, caused by disease / phatogen factor or environmental factor not good.The results of the laboratory analysis found six (6) parasites that infect tilapia: Dactyloyrus sp, Gyrodactylus spp, Tricodina sp, Vortycella sp, Oodinium sp, and Saprolegnia sp. Water quality is less good in the cultivation are resulted in the decreased condition of fish and support well the development of various types of parasites.
\end{abstract}

Keywords: Diagnosis, Analysis, Identification, Parasite, Tilapia, New Subak

\section{Pendahuluan}

Usaha budidaya ikan adalah salah satu usaha yang sangat mejanjikan akhir-akhir ini seiring dengan kian meningkatnya permintaan produk-produk perikanan di masyarakat akibat dari semakin kritisnya konsumen dalam hal memilih sumber bahan makanan yang sehat serta memiliki nilai gizi yang tinggi dengan harga yang terjangkau dan mudah didapatkan. Budidaya perikanan, seperti halnya usaha-usaha budidaya yang lain perkembangannya tidak luput dari berbagai kendala dan permasalahan. Salah satu masalah terbesar yang sering menghambat budidaya ikan adalah terjadinya serangan penyakit. Serangan penyakit dapat mengakibatkan kerugian secara ekonomi bahkan terkadang sampai menggagalkan produksi.

Setelah terbukanya perdagangan bebas antar negara-negara di dunia, sehingga seakan tidak lagi mengenal batas ruang, waktu dan letak geografis, yang berakibat pada peningkatan arus perdagangan barang dan jasa yang semakin cepat, demikian juga halnya dengan produk-produk perikanan. Seiring dengan meningkatnya lalu-lintas perdagangan komoditias perikanan akan berdampak pula terhadap kemungkinan menyebarnya suatu penyakit ikan dari satu darah ke daerah lain bahkan dari satu negara ke negara lainnya yang dapat merugikan dan merusak kelangsungan usaha budidaya serta kelestarian sumber daya alam hayati perikanan.

Penyakit ikan adalah suatu keadaan fisik, morfologi dan fungsi yang mengalami perubahan dari kodisi normal yang disebabkan oleh faktor internal dan eksternal. Ikan yang merupakan salah satu hewan air yang selalu bersentuhan dengan lingkungan perairan sehingga mudah terinfeksi penyakit melalui media air pada area budidaya. Air tidak semata hanya tempat hidup tapi juga sebagai perantara pathogen. Penyakit ikan dapat diakibatkan oleh penyebab jasad biologik dan non biologik. Penyakit yang disebabkan oleh jasad biologik disebut juga sebagai penyakit infeksi. Penyakit infeksi dapat dipindah sebarkan ke individu hewan lainnya dengan berbagai cara. 
Untuk menghindari kegagalan dalam usaha budidaya perikanan dan meluasnya serangan penyakit maka sangat diperlukan langkah-langkah penanganan dengan pencegahan dan melalui pengendalian. Penanganan dan pengendalian penyakit ikan akan berhasil dengan baik apabila pembudidaya memiliki pengetahuan yang cukup untuk dapat mengenali tanda-tanda ikan yang terserang penyakit atau mendiagnosa dan mengidentifikasi suatu penyakit sehingga dapat diambil suatu tindakan pengendalian dan pengobatan yang tepat.

Pengenalan tanda-tanda ikan yang terserang penyakit dapat dilakukan melalui dua cara yaitu pengenalan secara fisik dan tingkah laku di lapangan dan pengamatan secara klinis di laboraturium. Kedua pengamatan/diagnosa ini berkaitan sangat erat, mengingat ketepatan dalam melihat, mengamati dan memperhatikan kelainan fisik dan kelainan perilaku adalah langkah awal untuk menentukan cara pengendalian dan pemilihan obat. Sedangkan pengamatan di laboratorium adalah untuk memastikan dan mengidentifikasi jenis penyakitnya.

Setiap serangan parasit pada ikan akan menimbulkan gejala klinis pada ikan berupa kelainan pada tubuh maupun organ-organ lainnya yang biasanya dapat dikenali secara langsung dengan hanya melihat dan memperhatikan ikan secara seksama di lokasi budidaya. Disamping kelainan fisik ikan yang terserang penyakit juga akan menunjukkan kelainan prilaku. Kedua gejala klinis ini dapat digunakan untuk menduga jenis penyakit atau parasit yang menyerang ikan. Untuk mendapatkan kepastian atau keakuratan dari pendiagnosaan tersebut serta untuk mengidentifikasi jenis parasit atau organisme phatogen yang menyerang ikan maka pengamatan dengan menggunakan alat-alat bantu perlu dilakukan di laboratorium.

\section{Bahan dan Metode}

\subsection{Tempat dan Waktu Penelitian}

Penelitian ini dilaksanakan di kawasan pembenihan dan pembudidaya ikan Kelompok "Mina Ayu" di Desa Baru, Kecamatan Marga, Kabupaten Tabanan, selama 16 hari dari tanggal 25 Mei - 10 Juni 2017, sedangkan pengamatan laboratorium dan identifikasi penyakit dilaksanakan di Laboratorium Fakultas Pertanian Universitas Warmadewa Denpasar.

\subsection{Alat dan Bahan}

Alat-alat yang digunakan di lapangan dalam penelitian ini terdiri dari: jaring ukuran $3 \mathrm{~m} \times 4 \mathrm{~m} \times 1 \mathrm{~m}$, serok (alat tangkap), ember, kertas tissue, kamera digital, timbangan digital, penggaris, alat-alat tulis, plastik packing, tabung oksigen, box steroform, test kit DO, Tes kit amoniak $\left(\mathrm{NH}_{4}^{+}\right)$, tes kit nitrit $\left(\mathrm{NO}_{2}\right)$, $\mathrm{pH}$ Peper, thermometer air, sedangkan alat-alat yang digunakan di laboratorium yaitu: ember, scoope net, aerator, selang aerator, batu aerator, buku identifikasi parasit, mikroskop binokuler, deck glass dan cover glass, dissecting set/ alat-alat bedah, nampan plastic, kamera digital. Adapun bahan-bahan yang digunakan dalam penelitian ini yaitu: ikan nila, air sumur, immersion oil.

\subsection{Metode Penelitian}

Penelitian ini menggunakan metode penelitian diskriptif eksploratif, yaitu dengan melakukan serangkaian kegiatan pengamatan terhadap obyek yang diteliti dalam hal ini adalah ikan nila untuk melihat tanda-tanda/kelainan fisik yang terjadi pada ikan nila yang terserang penyakit, serta kelainan 
perilaku (behaviour). Teknik pengambilan data dalam penelitian ini dilakukan dengan observasi atau pengamatan langsung obyek yang diteliti di lapangan, dan pengamatan mikroskopis di laboratorium pada ikan sampel.

\subsection{Prosedur Penelitian}

\section{Persiapan Penelitian}

Persiapan yang dilakukan dalam penelitian ini meliputi:

\section{Survei Lokasi}

Survei lokasi dilakukan untuk menentukan dan memastikan telah terjadi kasus serangan penyakit ikan budidaya dalam hal ini khususnya ikan Nila yang terjadi di wilayah Subak Baru, Desa Baru, Kecamatan Marga, Kabupaten Tabanan. Dari lokasi ini ditentukan tiga (3) titik pengambilan sampel didasarkan pada jenis kolam atau kontruksi kolam, yaitu:

\section{a. Kolam Sawah (Titik I)}

Di mana kolam di sini adalah sebuah petakan sawah biasa yang ditinggikan dan ditebalkan sedikit pematangnya, sehingga ketinggian air bisa mencapai 20-30 cm, tanpa merubah kontrusi dari pada sawah.

b. Kolam dari Terpal Plastik (Titik II)

Kolam yang dibuat dari terpal plastik yang dibuat sebagaimana layaknya kolam dan ketinggian air mencapai 50-60 cm.

c. Kolam Kontruksi Dinding Beton (Titik III)

Kolam dengan kontruksi dinding beton, namun dasar kolam masih tetap tanah. Ketinggian air mencapai $70-80 \mathrm{~cm}$.

\section{Pengambilan Sampel}

Pengamatan sampel di laboratorium dilakukan secara mikroskopis untuk mengidentifikasi jenis parasit yang menginfeksi ikan sampel. Pengamatan mikroskopis dilakukan dengan pengambilan sampel ikan uji dari dalam kolam budidaya di lapangan pada tiga tempat yang berbeda. Ikan di ambil secara acak sebanyak 20 ekor untuk setiap lokasi.

\section{Pelaksanaan Penelitian}

\section{Pengamatan Perilaku Ikan}

Pengamatan perilaku ikan dilakukan secara visual di kolam yang mengalami serangan penyakit dengan memperhatikan dan mencatat hal-hal sebagai berikut: (1) Pola gerakan renang daripada ikan, apakah berenangnya normal, tidak aktif berenang. (2) Berenang miring. (3) Berenang berputar-putar. (4) Meloncat-loncat di permukan kolam. (5) Menggantung di permukaan air. (6) Menempel di dinding kolam. (7) Bergerombol di pintu pemasukan air. (8) Menyendiri dan terlepas dari gerombolannya. (9) Tidak respon terhadap makanan. (10) Tidak respon terhadap kejutan.

2. Pengamatan terhadap kelainan fisik, antara lain:

(1) Pengamatan tubuh. (2) Pengamatan sisik. (3) Pengamatan sirip. (4) Pengamatan insang dan tutup insang. (5) Pengamatan kepala (torax). (6) Pengamatan mata. (7) Pengamatan dubur dan lubang kelamin. 
3. Pengamatan Faktor Kondisi

Faktor kondisi ikan diamati dengan mengambil sampel ikan pada masing-masing lokasi pemantau sejumlah 20 ekor yang selanjutnya dihitung faktor kondisinya dengan menggunakan rumus seperti disampaikan Sutjiati (1990), sebagai berikut:

$$
\mathrm{R}=\text { Faktor kondisi }=\frac{\mathrm{W}}{\mathrm{TL}^{3}} \times 100 \%
$$

Keterangan:

$\mathrm{R}=$ faktor kondisi, $\mathrm{W}=$ berat ikan sampel dalam gram (gr), $\mathrm{TL}=$ panjang total ikan sampel dalam centimeter (cm). Nilai $\mathrm{R}=1,7$ Kondisi ikan masih bagus/sehat, apabila nilai $\mathrm{R}<$ dari 1,7 berarti kondisi ikan kurang baik atau tidak sehat.

\section{Pengamatan Kualitas Air}

a. Suhu

Suhu diamati dengan termometer alkohol dengan cara mencelupkan langsung termometer tersebut ke dalam air dengan kedalaman kurang lebih 10-15 $\mathrm{cm}$ di bawah permukaan air selama kurang lebih 1 menit yang selanjutnya dilakukan pembacaan skala langsung pada saat termometer masih di dalam air.

b. Oksigen $\left(\mathrm{O}^{2}\right)$ Terlarut

Oksigen terlarut diukur dengan Test Kitt oksigen sebagai berikut: air sampel diambil sebanyak $5 \mathrm{ml}$ dengan menggunakan botol berskala yang telah tersedia pada test kitt, selanjutnya air sampel ditetesi dengan reagent 1 sebanyak 5 tetes, kemudiaan ditambahkan reagen 2 sebanyak 5 tetes dan sampel dikocok selama 30 detik kemudian ditambahkan reagen 3 sebanyak 10 tetes dan dikocok kembali. Kemudian dilakukan pengamatan perubahan warna air dan dicocokkan dengan skala warna yang tersedia di mana masing-masing warna telah memeliki nilai tersendiri yang menunjukkan kadar oksigen dalam satuan ppm.

c. $\mathrm{pH}$

$\mathrm{pH}$ diamati dengan $\mathrm{pH}$ paper (kertas $\mathrm{pH}$ ) dengan jalan mencelupkan satu streep $\mathrm{pH}$ paper ke dalam air selama beberapa menit, selanjutnya diangkat dan diangin-anginkan sebentar dan dilakukan pencocokan perubahan skala warna sesuai dengan skala yang ada pada kotak $\mathrm{pH}$ paper tersebut dan dicatat sesuai dengan angka pada kominasi warna mana yang paling cocok.

\section{d. Amonium $\left(\mathrm{NH}_{3}\right)$}

Amonium juga diukur dengan amonium-test kit, dengan langkah sebagai berikut: ambil air sampel sebanyak $5 \mathrm{ml}$ dengan botol sampel yang tersedia, tambahkan reagent 1 sebanyak 10 tetes, kemudian tambahkan reagen 2 yang dalam bentuk serbuk satu sendok takaran lalu ditutup dan dikocok sampai reagen larut, selanjutnya ditambahkan reagent 3 sebanyak 6 tetes, setelah lima menit warna yang terjadi dicocokkan dengan tabel skala warna yang tersedia sehingga amonium dapat ditentukan (ppm).

e. Nitrat $\left(\mathrm{NO}_{3}^{-}\right)$

Nitrat diukur dengan menggunakan Nitrat-Test kit, dengan prosedur sebagai berikut: diambil air sampel sebanyak $5 \mathrm{ml}$ dengan menggunakan botol sampel yang telah tersedia pada nitrat-tes kit, selanjutnya ditambahkan reagen yang dalam betnuk serbuk sebanyak satu sendok takar yang telah 
tersedia, kemudian ditutup dan dikocok selanjutnya didiamkan selama 5 menit dan diamati perubahan warnanya, warna kemudiaan dicocokkan dengan tabel warna berskala sehingga kadar nitrat dapat ditentukan (ppm).

\section{Pengamatan Sampel di Laboratorium}

Pengamatan sampel di laboratorium dilakukan secara mikroskopis untuk mengidentifikasi jenis parasit yang menginfeksi ikan sampel. Setelah didapatkan data jenis parasit/penyakit yang menyerang ikan kemudian dilakukan penghitungan prevalensi atau tingkat serangan suatu jenis parasit/penyakit dalam prosen, dengan rumus penghitungan sebagai berikut:

$$
\text { Prevalensi }=\frac{\sum \text { ikan terserang parasit "A" }}{\sum \text { ikan yang diperiksa }} \times 100 \%
$$

\subsection{Analisa Data}

Data yang didapat dari hasil penelitian ini akan dikumpulkan dan dianalisa secara deskriptif dan selanjutnya akan dibahas dan ditampilkan dalam bentuk gambar dan tabel sehingga akan bisa diambil suatu kesimpulan.

\section{Hasil dan Pembahasan}

\subsection{Hasil Pengamatan Perubahan Penotipe Tubuh Ikan Nila yang Teserang Penyakit}

\section{Perubahan Perilaku}

Perubahan perilaku (behaviour) adalah perubahan yang terjadi pada ikan yang terserang penyakit. Pada penelitian ini terdapat beberapa perubahan perilaku yang teramati, antara lain:

a. Terjadi penurunan nafsu makan dan respon terhadap makanan pada saat ikan diberikan makan, terutama pada pagi dan sore hari.

b. Respon terhadap kejutan sangat kurang dan gerakan ikan menjadi sangat lambat dan cenderung pasif.

c. Berenangnya tidak beraturan. Ikan yang sakit juga menunjukkan perubahan dalam hal berenangnya yaitu, terkadang berenangnya miring dan berputar-putar tidak tentu arah, ada juga yang renangnya seolah menghentak setelah itu diam.

d. Pernafasan ikan yang sakit sangat cepat terlihat dari pola pergerakan membuka dan menutupnya overcolum atau tutup insang yang frekuensinya sangat cepat.

Handajani dan Samsundari, (2005) menyatakan beberapa hal dan gejala yang ditunjukkan oleh ikan yang terserang penyakit adalah diawali dengan penurunan nafsu makan, gerakan melambat, pernafasan cepat seperti kekurangan oksigen, berenang miring karena kehilangan keseimbangan, sering berkumpul tidak wajar di pintu pemasukan air dan tidak respon terhadap kejutan.

\section{Warna Tubuh}

Ikan nila yang mengalami perubahan perilaku juga mengalami perubahan warna yang terlihat sangat jelas perbedaannya dibandingkan ikan yang masih sehat. Warna tubuh ikan perlahan-lahan akan berubah menjadi agak gelap tidak seperti keadaan normal berwarna putih keperakan mengkilat (silver), semakin lama akan berubah menjadi hitam pekat, dalam keadaan warna yang demikian maka di kolam ikan yang sakit terlihat sangat jelas karena warnanya sangat berbeda dengan yang lainya. 


\section{Pendarahan Tubuh (haemoragik)}

Ikan Nila yang terindikasi terserang penyakit, setelah diamati secara seksama tubuh dan organ-organ tubuhnya selain warnanya menunjukkan beberapa kelainan atau perubahan dari keadaan yang normal, seperti terlihat beberapa kelainan pada organ luar ikan nila yaitu terjadi pendarahan (haemoragik) yang cukup parah pada insang dan beberapa bagian tubuh lainnya seperti pada pangkal sisik, pangkal sirip terutama pada sirip ekor dan sirip perut. Sirip terlihat banyak yang putus atau geripis dan sisik juga banyak lepas terutama dibagian yang mengalami pendarahan.

Menurut Hanjani dan Samsundari (2005), Irianto (2005), menyatakan terjadi pendarahan (haemoragik) pada organ, pembengkakan pada hati dan empedu, tidak adanya sisa pakan pada lambung dan usus sudah mengindikasikan ikan terserang penyakit oleh berbagai parasit dan kemungkinan juga sudah tertular oleh bakteri patogen. Gejala seperti tersebut sering terjadi pada ikan nila akibat serangan parasit sebagai penyakit primer dan diikuti oleh penyakit skunder sehingga lama kelamaan tubuh ikan seperti borok/membusuk (Anonimus, 2003).

\section{Bentuk Tubuh}

Ikan yang sakit kebanyakan memiliki kelainan bentuk tubuh, seperti ukuran tubuh yang tidak proporsional antara panjang dengan lebarnya, yaitu panjangnya sangat jauh melebihi lebarnya sehingga ikan kelihatan sangat kurus, terkadang ikan juga bengkok pada batang ekornya. Tubuhnya kurus dan panjang jika dibandingkan dengan lebar kepalanya juga menjadi tidak proporsional, terlihat seperti ikan kebesaran kepala.

Zonneveld et al. (1991), menyatakan ikan yang terserang penyakit walaupun pada bagian luar tubuh, seperti kulit, sisik, sirip dan insang akan mengakibatkan nafsu makannya akan berkurang bahkan tidak mau makan sama sekali.

\section{Organ Insang}

Insang ikan nila yang menunjukkan gejala terserang penyakit, pada organ insangnya juga mengalami gangguan yaitu berupa perubahan warna tapis insang yang berwarna merah pucat atau pink tidak seperti ikan sehat yang warnanya merah hati atau merah darah, dan apabila sudah kronis warna insangnya berwarna coklat. Tapis insang justru menggumpal menjadi satu, sedangkan untuk insang yang sehat antara satu lembar dengan lembar yang lainnya terpisah dengan baik.

Anonimus (1993), menyebutkan bahwa gejala penyakit seperti ini yang sering merugikan karena dengan cepat dapat mematikan ikan secara massal yang disebabkan oleh serangan berbagai parasit dan bakteri bahkan juga virus.

\subsection{Pengamatan Kelainan Organ dalam yang Dilakukan di Lapangan}

Ikan yang mengalami kelainan fisik tersebut kemudian beberapa diambil sebagai sampel untuk diamati organ dalamnya, hal ini bertujuan untuk memastikan apakah organ dalamnya mengalami kelainan juga seperti pada organ luarnya. Hasil pembedahan maka terlihat organ yang paling mencolok mengalami kelainan adalah pembengkakan empedu, pada rongga perut mengandung cairan berwarna hitam pekat, lambung dan usus cendrung kosong tidak ada sisa makanan maupun makanan yang masih segar, hal ini menunjukkan bahwa ikan sudah relatif lama tidak mengkonsumsi makanan. 
Menurut Hanjani dan Samsundari (2005), Irianto (2005), menyatakan terjadi pendarahan (haemoragik) pada organ, pembengkakan pada hati dan empedu, tidak adanya sisa pakan pada lambung dan usus sudah mengindikasikan ikan terserang penyakit oleh berbagai parasit dan kemungkinan juga sudah tertular oleh bakteri patogen. Pembengkakan pada hati dan empedu, besar kemungkinan bukan karena penyakit primer, melainkan merupakan komplikasi dari terjadi serangan parasit lebih dahulu yang menyerang organ-organ fital, seperti insang misalnya yang menyebabkan darah tidak dapat menyuplai oksigen ke seluruh tubuh sehingga kondisi ikan menjadi semakin lemah yang akibatnya bakteri patogen mudah menyerang karena sistem imun atau kekebalan tubuh pada ikan menurun (Irianto, 2005).

Menurunnya daya pertahanan tubuh ikan akan memudahkan patogen sekunder (misalnya bakteri) menyerang (Anonimus, 2002). Zonneveld et al. (1991), menyatakan ikan yang terserang penyakit walaupun pada bagian luar tubuh, seperti kulit, sisik, sirip dan insang akan mengakibatkan nafsu makannya akan berkurang bahkan tidak mau makan sama sekali.

\subsection{Faktor Kondisi Ikan Nila}

Setelah melakukan pengamatan secara fisual terhadap ikan Nila di lokasi penelitian maka dilanjutkan dengan menentukan faktor kondisi pada ikan dengan cara mengambil ikan sampel pada tempat yang berbeda-beda. Adapun jumlah sampel yang diambil adalah sebanyak 20 ekor untuk setiap tempat. Hasil penghitungan faktor kondisi di lokasi I tertera pada Tabel 1 sebagai berikut:

Tabel 1

Faktor Kondisi Ikan Nila pada Lokasi I

\begin{tabular}{ccccc}
\hline No. & Berat $(\mathrm{gr})$ & Panjang $(\mathrm{cm})$ & Faktor Kondisi & Kategori \\
\hline 1 & 22 & 10,5 & 1,900442717 & Sehat \\
2 & 55 & 14,5 & 1,804092009 & Sehat \\
3 & 39 & 13 & 1,775147929 & Sehat \\
4 & 20 & 10,6 & 1,679238566 & sakit \\
5 & 30 & 12,3 & 1,612151755 & sakit \\
6 & 54 & 14,3 & 1,846654495 & Sehat \\
7 & 37 & 13,2 & 1,608718034 & sakit \\
8 & 33 & 13 & 1,502048248 & sakit \\
9 & 23 & 10,5 & 1,986826477 & Sehat \\
10 & 18 & 10,2 & 1,696180202 & sakit \\
11 & 12 & 9 & 1,646090535 & sakit \\
12 & 9 & 8 & 1,7578125 & Ambang batas \\
13 & 7 & 7 & 2,040816327 & Sehat \\
14 & 11 & 8,9 & 1,560352299 & sakit \\
15 & 5 & 6,5 & 1,820664543 & Sehat \\
16 & 6 & 7,3 & 1,542349049 & sakit \\
17 & 5 & 6,8 & 1,59016894 & sakit \\
18 & 4 & 6,7 & 1,329950825 & sakit \\
19 & 4 & 6,3 & 1,599699257 & sakit \\
20 & 4 & 6,3 & 1,599699257 & sakit \\
\hline
\end{tabular}

Sumber: Diolah dari Data Primer, Tahun 2017

Tabel 1 di atas terlihat bahwa sebagian besar ikan sampel nilai faktor kondisinya berada di bawah 1,7 yaitu mencapai $60 \%$ yang berarti bahwa $60 \%$ dari populasi ikan sudah sakit, karena ikan yang memiliki nilai di bawah 1,7 termasuk katagori kondisi ikan sudah tidak bagus/sakit, sedangkan faktor kondisi 1,7 termasuk katagori masih sehat tetapi sudah agak riskan apabila terjadi kekurangan beberapa faktor pendukung misalnya ketersediaan pakan, dan kondisi lingkungan. Katagori masih sehat hanya 
$35 \%$ dan yang berada dalam kondisi ambang batas antara sehat dan sakit sebanyak 5\%. Melihat dari data tersebut di atas maka sudah dapat dipastikan di area budidaya tepatnya di lokasi I sudah terjadi wabah penyakit yang cukup parah.

Faktor kondisi ikan 60\% yang berada di bawah ambang batas sehat atau kondisi ikan dalam keadaan buruk yang kemungkinan besar karena faktor penyakit/organisme patogen yang didukung oleh faktor lingkungan, maka sangat besar kemungkinan pada suatu saat akan terjadi kematian ikan secara masal apabila situasi ini tidak ditangani dengan segera, yaitu dengan mengadakan diagnosa dan identifikasi jasad penyakit/patogen dan selanjutnya melakukan pengobatan yang tepat, baik tepat obat dan tepat dosis, tepat sasaran, dan tepat cara penggunaanya. Walaupun 35\% persen masih ada ikan yang termasuk katagori sehat, tetapi karena jumlah yang sakit jauh lebih banyak maka kemungkinan tertular akan menjadi lebih besar dan lebih cepat. Pada saat pemantauan dan sekaligus pengambilan sampel kematian ikan sudah terjadi walaupun belum terlalu banyak, namun kematian semakin bertambah banyak dari hari ke hari sesuai dengan informasi pembudidaya.

Faktor kondisi ikan pada daerah pengambilan sampel II menunjukkan hal yang tidak jauh berbeda dengan lokasi I di mana hasilnya disajikan pada Tabel 2 di bawah.

Tabel 2

Faktor kondisi Ikan Nila di Lokasi II

\begin{tabular}{ccccc}
\hline No. & Berat $(\mathrm{gr})$ & Panjang $(\mathrm{cm})$ & Faktor Kondisi & Katagori \\
\hline 1 & 50 & 14,9 & 1,511510607 & Sakit \\
2 & 14 & 9,3 & 1,740520689 & Ambang batas \\
3 & 28 & 11,6 & 1,793841486 & Sehat \\
4 & 6 & 7,1 & 1,676394411 & Sakit \\
5 & 5 & 5,9 & 2,434523491 & Sehat \\
6 & 6 & 7,2 & 1,607510288 & Sakit \\
7 & 7 & 8 & 1,3671875 & Sakit \\
8 & 8 & 8 & 1,5625 & Sakit \\
9 & 31 & 12,3 & 1,665890147 & Sakit \\
10 & 6 & 7,4 & 1,480662547 & Sakit \\
11 & 7 & 8 & 1,3671875 & Sakit \\
12 & 11 & 8,3 & 1,923793301 & Sehat \\
13 & 9 & 8,3 & 1,574012701 & Sakit \\
14 & 2 & 7,6 & 0,455605773 & Sakit \\
15 & 7 & 7,2 & 1,875428669 & Sehat \\
16 & 6 & 7,5 & 1,422222222 & Sakit \\
17 & 7 & 7 & 2,040816327 & Sehat \\
18 & 6 & 7 & 1,749271137 & Ambang batas \\
19 & 6 & 7,3 & 1,542349049 & Sakit \\
20 & 9 & 8 & 1,7578125 & Ambang batas \\
\hline
\end{tabular}

Sumber: Diolah dari Data Primer, Tahun 2017

Tabel tersebut terlihat bahwa 65\% ikan nila telah berada pada kondisi yang tidak baik atau sudah sakit, yaitu lebih tinggi dari lokasi I, sedangkan ikan yang masih dalam kondisi baik atau sehat adalah hanya $25 \%$ dan yang berada pada kondisi ambang batas nilai terendah katagori baik/sehat $5 \%$ sama dengan lokasi I. Hal tersebut terlihat bahwa pada lokasi II justru kondisi ikan lebih parah dibandingkan dengan lokasi I, walaupun dari sisi jumlah kematian tidak jauh berbeda dari dengan lokasi I, namun pada suatu waktu kematian pada lokasi II bisa dipastikan akan lebih banyak dari lokasi I dan kemungkinan kematian secara masal bisa lebih cepat terjadi.

Pada lokasi pemantauan III ( Tabel 3) justru menunjukkan hal yang paling berbeda di mana pada 
lokasi ini tidak ada lagi katagori ikan yang masih sehat atau kondisinya cukup baik karena 95\% ikan sudah berada pada kondisi yang tidak baik sedangkan $10 \%$ berada pada kondisi yang berada di ambang batas terendah katagori kondisi ikan yang sehat.

Pada lokasi III ini dari hasil pemantauan terlihat jumlah ikan yang mati jauh lebih banyak dari lokasi I dan II , bahkan ikan-ikan yang mati tidak saja mengambang di permukaan kolam tetapi sudah sangat banyak yang berada di dasar kolam dan kondisi yang sudah membusuk, berbeda dengan lokasi I dan II ikan yang mati masih lebih banyak mengambang di permukaan dan hanya sedikit yang ada di dasar kolam. Hal yang paling berbeda pada lokasi III adalah sudah terjadi bau busuk yang sangat menyengat, sedangkan pada loksi I dan II hal ini belum terjadi.

Melihat dari ketiga lokasi tersebut, tingkat keparahan berurut dari lokasi I, II, dan III hal ini kemungkinan kontruksi kolam adalah hal yang paling berpengaruh karena selain perbedaan kontruksi hal yang lainnya relatif sama, yaitu sumber airnya sama, keadaan cuaca juga tidak jauh berbeda, jenis pakan juga sama.

Perbedaan kontruksi kolam (kolam sawah, kolam terpal, dan kolam beton, besar kemungkinan akan berpengaruh terhadap kualitas lingkungan perairan di tempat pemeliharaan, mengingat pada saat terjadi wabah penyakit ini sedang terjadi penurunan debit air akibat adanya perbaikan irigasi pada saluran utama atau primer, debit air yang berkurang ini tentu akan berpengaruh terhadap kualitas air pada kolam budidaya, kontruksi kolam akan turut pula dalam mempengaruhi penurunan kualitas air tersebut. Fluktuasi suhu yang tinggi dan kandungan oksigen serta kandungan bahan-bahan yang bersifat racun pada kolam akibat sedikitnya terjadi pergantian air di kolam kemungkinan sebagai penyebab parahnya serangan penyakit pada kasus ini. Menurut Irianto (2005), kualitas air, volume air dan alirannya berpengaruh terhadap berkembangnya suatu penyakit. Terdapat banyak faktor yang menentukan seekor ikan menjadi sakit. Faktor utamanya adalah Host (organisme peliharaan/inang), Pathogen (microba, parasit) dan Environment (lingkungan menyangkut fisik, kimia atau tingkah laku seperti stress). Penyakit ini dapat dikelompokkan berdasarkan faktor penyebabnya yaitu lingkungan (dalam hal ini air sebagai media hidup, parameter-parametenya yaitu suhu, $\mathrm{pH}$, oksigen terlarut, senyawa beracun, kekeruhan/kecerahan air, salinitas) dan pakan. Menurut Afrianto dan Liviawaty (1992), penyakit ikan adalah segala sesuatu yang dapat menimbulkan gangguan pada ikan, baik secara langsung maupun tidak langsung.

Tabel 3

Faktor Kondisi Ikan Nila di Lokasi III

\begin{tabular}{ccccc}
\hline No. & Berat (gr) & Panjang (cm) & Faktor Kondisi & Katagori \\
\hline 1 & 6 & 7,4 & 1,480662547 & Sakit \\
2 & 51 & 14,6 & 1,638745865 & Sakit \\
3 & 8 & 8 & 1,5625 & Sakit \\
4 & 6 & 8 & 1,171875 & Sakit \\
5 & 3 & 5,7 & 1,619931639 & Sakit \\
6 & 17 & 10 & 1,7 & Ambang batas \\
7 & 31 & 12,3 & 1,665890147 & Sakit \\
8 & 14 & 8,8 & 2,054376409 & Sehat \\
9 & 15 & 9,5 & 1,74952617 & Ambang batas \\
10 & 7 & 8,4 & 1,181027967 & Sakit \\
11 & 5 & 7,4 & 1,233885456 & Sakit \\
12 & 10 & 8,8 & 1,467411721 & Sakit \\
13 & 9 & 8,6 & 1,414969751 & Sakit \\
14 & 4 & 6,7 & 1,329950825 & Sakit \\
\hline
\end{tabular}


Diagnosa, Analisis dan Identifikasi Parasit yang Menyerang Ikan Nila (Oreochromis Niloticus) Pada Kawasan Budidaya Ikan Di Subak "Baru” Tabanan

\begin{tabular}{ccccl}
\hline 15 & 6 & 7,5 & 1,422222222 & Sakit \\
16 & 10 & 9 & 1,371742112 & Sakit \\
17 & 5 & 7,3 & 1,285290874 & Sakit \\
18 & 9 & 8,4 & 1,518464529 & Sakit \\
19 & 7 & 7,8 & 1,47507544 & Sakit \\
20 & 7 & 8 & 1,3671875 & Sakit \\
\hline
\end{tabular}

Sumber: Diolah dari Data Primer, Tahun 2017

\subsection{Hasil Pengamatan Laboratorium}

Setelah dilakukan pemantauan di lapangan maka untuk dapat memastikan dan mengidentifikasi parasit/penyakit yang menginfeksi ikan Nila pada ketiga lokasi tersebut selanjutnya dilakukan pengamatan dilaboratorium, dengan mengambil 10 ekor ikan nila sebagai sampel di masing-masing lokasi. Hasil pengamatan di laboratorium secara keseluruhan ditemukan enam jenis parasit yang menyerang ikan sampel yaitu Dactyloyrus sp, Gyrodactylus spp, Tricodina sp, Vortycella sp, Oodinium sp, dan jamur.

\section{Dactylogyrus sp}

Datylogyrus sp ini ditemukan pada bagian insang ikan nila dalam jumlah yang relatif banyak, menyebabkan terjadinya sekresi mucus/lendir yang berlebihan pada insang dan menyebabkan tepi lamela (tapis insang) lengket antara satu lembar dengan yang lainnya sehingga seperti menggumpal. Menurut Irianto (2005), parasit ini memiliki keragaman siklus hidup dan spesies inang.

Dactylogurus adalah parasit yang sering merugikan pembudidaya dalam jumlah yang besar, karena perkembangan dan penularannya yang begitu cepat dengan sifat serangan yang mematikan karena cenderung menyerang organ vital dari ikan yaitu organ pernafasan. Klasifikasi parasit ini menurut Handajani dan Samsundari, (2005) adalah sebagai berikut:

$\begin{array}{ll}\text { Phylum } & : \text { Platyhelminthes } \\ \text { Class } & : \text { Trematoda Monogenia } \\ \text { Ordo } & : \text { Dactylogyridea } \\ \text { Famili } & : \text { Dactylogiridae } \\ \text { Genus } & : \text { Dactylogyrus } \\ \text { Species } & : \text { Dactyligirus sp }\end{array}$

\section{Gyrodactylus spp}

Parasit ini masih tergolong Nematoda Monogenia dan masih merupakan kerabat sangat dekat dengan Dactylogyrus. Gyrodactylus ditemukan pada bagian kulit atau permukaan tubuh ikan dan juga sirip, menyebabkan ikan mengeluarkan lendir yang berlebihan pada permukaan tubuh, sisik mudah lepas dan sirip geripis, menimbulkan gatal sehingga ikan seing menggosok-gosokkan tubuh di dasar perairan atau subtrat, warna ikan menjadi tidak cerah (kusam) bahkan warnya berubah menjadi gelap dan hitam.

Adapun klasifikasi dari Gyrodactylus spp adalah sebagai berikut:

Phylum : Platyhelminthes

Class : Trematoda monogenia 


\begin{tabular}{ll}
\hline Ordo & : Gyrodactylidea \\
Family & $:$ Gyrodactylidae \\
Genus & $:$ Gyrodactylus \\
Species & $:$ Gyrodactylus spp
\end{tabular}

\section{Tricodina spp}

Tricodina spp parasit ini di temukan pada bagian tubuh ikan Nila yaitu di bagian kulit, sirip dan insang, yang menyebabkan iritasi pada bagian tubuh ikan. Ikan akan merasa gatal sehingga sering menggosok-gosokkan tubuhnya di pematang kolam atau benda-benda keras lainnya. Ikan yang terserang parasit ini sering menggesek-gesekan tubuhnya di dasar kolam atau pada benda-benda/subrat yang ada di dalam kolam sehingga memicu kemungkinan terjadinya luka pada tubuh yang memungkinkan parasit lain juga menyerang dengan cepat seperti jamur Saprolegnia.

Parasit ini akan berkembang biak dengan cepat pada kolam yang dangkal dan relatif tergenang (sirkulasi air kurang bagus), serta penumpukan bahan organik yang tinggi dan terurai di dasar kolam (Anonimus, 2008). Parasit ini dapat diklasifikasikan sebagai berikut:

$\begin{array}{ll}\text { Phylum } & \text { : Ciliophora } \\ \text { Subphylum } & \text { : Hypostomata } \\ \text { Class } & \text { : Oligomenophorea } \\ \text { Ordo } & : \text { Sessilida } \\ \text { Famili } & : \text { Tricodinidae } \\ \text { Genus } & : \text { Tricodina } \\ \text { Species } & : \text { Tricodina } s p\end{array}$

\section{Vorticella sp}

Vorticella memiliki satu individu tiap tangkainya. Berkembang biak dengan cara bertunas dan konjugasi. Pada saat pengamatan vorticella tidak ditemukan dalam jumlah yang banyak, seperti halnya dengan parasit yang lainnya dan ditemukan tidak pada semua sampel, sehingga bisa dipastikan kematian ikan nila tidak disebabkan oleh vorticella sp, tetapi parasit ini hanya membantu memperparah tingkat serangan oleh parasit yang lain.Vorticella ditemukan bersama-sama dengan parasit lainnya di insang terutama Dactylogirus.

Dana dkk (1994) dalam Anonimus (2011), Vorticella ditemukan bersama-sama dengan parasit lainnya di insang terutama Dactylogirus. Vorticella sp diklasifikasikan sebagai berikut:

$\begin{array}{ll}\text { Domain } & \text { : Eukaryota } \\ \text { Kingdom } & \text { : Chromalveolata } \\ \text { Superphylum } & : \text { Alveolata } \\ \text { Phylum } & : \text { Ciliophora } \\ \text { Subphylum } & : \text { Intramacronucleata } \\ \text { Class } & : \text { Oligohymenophorea } \\ \text { Subclass } & : \text { Peritrichia }\end{array}$




\begin{tabular}{ll}
\hline Ordo & $:$ Peritrichida \\
Family & $:$ Vorticellidae \\
Genus & $:$ Vorticella \\
Species & $:$ Vorticella $\mathrm{sp}$
\end{tabular}

\section{Oodinium sp}

Oodinium sp. adalah jenis Flagellata yang termasuk golongan protozoa, namun beberapa sumber mengatakan bahwa Oodinium sp ini masuk kategori algae karena memiliki klorofil Anonim (2011). Oodinium $s p$ merupakan salah satu parasit yang sering menyerang pada kondisi ikan yang sedang stress. Oodinium sp dapat menyerang ikan air tawar maupun laut, di mana untuk air tawar disebabkan oleh Oodinium pilularis atau Oodinium limneticum dan untuk ikan air laut disebabkan oleh Oodinium ocellatum.

Gejala klinis pada Oodinium di mulai dari sirip ikan, tahapan lebih lanjut akan terlihat seperti memakai bedak atau bertaburan tepung, ini yang disebut velvet. Pada tahapan berikutnya, potongan sisik atau kulit dari ikan akan terkelupas, pada mata akan terlihat adanya selaput seperti kabur dan kemudian menyerang seluruh bagian tubuh. Infeksi Oodinium $s p$ disebabkan karena penetrasi akan rizoid ke sel epitel inang, sehingga menyebabkan nekrosis, pendarahan dan mengalami infeksi sekunder oleh bakteri dan jamur.

Oodinium akan menempel pada ikan dengan menggunakan flagellum yang kemudian akan membentuk batang (kaki) penghisap yang masuk ke dalam kulit dan selaput lendir pada insang ikan. Batang (kaki) penghisap ini akan merusak sel-sel disekitamya dan menghisap nutrisi pada daging ikan (inang) sebagai makanannya (Anonim 2011). Kabata (1985), menjelaskan bahwa infeksi Oodinium sp disebabkan karena penetrasi akan rizoid ke sel epitel inang, sehingga menyebabkan nekrosis, pendarahan dan mengalami infeksi sekunder oleh bakteri dan jamur. Klasifikasi dari Oodinium sp, antara lain:

Phylum : Sarcomastigophora

Ordo : Dinoferida

Family : Blastodinidae

Genus : Oodinium

Species : Oodinium spp

\section{Saprolegnia sp}

Saproleginia adalah parasit yang tergolong ke dalam jamur atau fungi yang sering disebut penyakit mikosis. Saprolegnia adalah penyakit oportunis atau penyakit skunder karena infeksinya didahului atau difasilitasi oleh adanya luka atau borok pada tubuh ikan. Kematian yang ditimbulkan oleh Saprolegnia menurut Irianto (2005), umumnya akibat masalah osmosis atau respirasi yaitu bila area yang terinfeksi terjadi pada bagian kulit atau insang cukup luas atau berat.

Saprolegnia akan menyerang luka pada tubuh ikan dan menyebar ke jaringan-jarongan yang masih sehat di sekitarnya. Penyerangan akan semakin parah apabila dipicu oleh lingkungan sekitarnya yang memburuk misalnya suhu perairan yang tidak stabil atau cendrung lebih rendah dari keadaan normal, kadar amoniak yang tinggi, kandungan bahan organik yang tinggi. Penyerangan akan semakin parah 
apabila dipicu oleh lingkungan sekitarnya yang memburuk misalnya suhu perairan yang tidak stabil atau cendrung lebih rendah dari keadaan normal, kadar amoniak yang tinggi, kandungan bahan organik yang tinggi Irianto (2005), Handajani dan Samsundari (2005).

Saprolegnia dapat diklasifikasikan sebagai berikut:

$\begin{array}{ll}\text { Kingdom } & \text { : Fungi } \\ \text { Divisi } & \text { : Oomycotina } \\ \text { Phylum } & \text { : Phycomycetes } \\ \text { Class } & \text { : Oomycetes } \\ \text { Ordo } & \text { : Saprolegnialis } \\ \text { Famili } & \text { : Saprolegniaceae } \\ \text { Genus } & \text { : Saprolegnia } \\ \text { Spesies } & \text { : Saprolegnia Sp }\end{array}$

\begin{tabular}{|c|c|c|c|}
\hline No. & Jenis Parasit & No. & Jenis Parasit \\
\hline & Dactylogyrus sp & & Vorticella sp \\
\hline 1. & & 4. & \\
\hline
\end{tabular}

Gyrodactylus spp

Oodinium $s p$

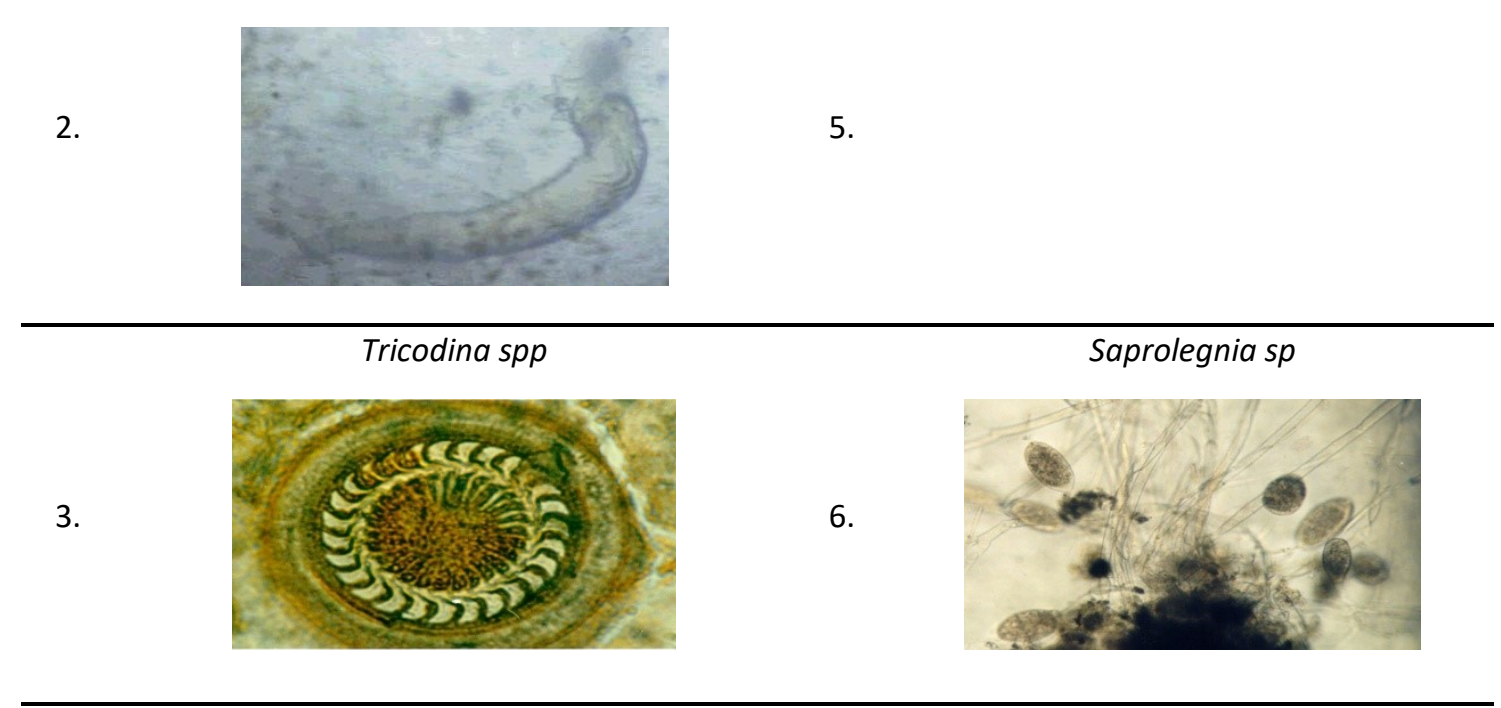

Gambar 1

Enam Jenis Parasit Yang Menyerang Ikan Pada Hasil Pengamatan Laboratorium

\subsection{Prevalensi}


Prevalensi atau frekuensi kejadian adalah besarnya persentase ikan yang terinfektasi oleh parasit tertentu dari ikan sampel yang diperiksa, tujuannya adalah untuk menentukan tingkat serangan suatu jenis parasit terhadap populasi ikan yang ada pada tempat budidaya. Pada lokasi I (satu) yang merupakan kolam sawah prevalensi masing-masing jenis parasit dari enam parasit yang ditemukan ternyata menunjukkan tingkat serangan yang berbeda-beda. Adapun prevalensi masing-masing jenis tersebut seperti ditunjukkan pada Tabel 4.

Tabel 4

Prevalensi Jenis Parasit pada Lokasi I

\begin{tabular}{ccc}
\hline No. & Nama Parasit & Prevalensi (\%) \\
\hline 1 & Dactyrogilus $s p$ & 30 \\
2 & Gyrodactilus & 30 \\
3 & Tricodina $s p$ & 40 \\
4 & Vorticella $s p$ & 10 \\
5 & Oodinium $s p$ & 10 \\
6 & Saprolegnia $s p$ & 20 \\
\hline
\end{tabular}

Sumber: Diolah dari Data Primer, Tahun 2017

Tabel 4 di atas terlihat bahwa Tricodina sp memiliki prevalensi yang tertinggi yaitu mencapai $40 \%$ yang berarti bahwa 40\% ikan sudah terinfeksi Tricodina, kemudian diikuti oleh Dactyrogilus sp 30\%, kemudian Saprolegnia sp 20\%, Gyrodactilus sp 30\% dan vortycella sp dan Oodinium sp samasama10\%. Dari nilai prevalensi tersebut terlihat bahwa kematian ikan, atau sakitnya ikan nila disebabkan oleh banyak jenis parasit atau komplikasi berbagai jenis parasit. Pada lokasi II (dua) yang merupakan kolam terpal prevalensi masing-masing jenis parasit dari enam parasit yang ditemukan ternyata juga menunjukkan tingkat serangan yang berbeda-beda seperti halnya pada lokasi satu. Adapun prevalensi masing-masing jenis tersebut seperti ditunjukkan pada Tabel 5 berikut:

Tabel 5

Prevalensi Jenis Parasit pada Lokasi II

\begin{tabular}{ccc}
\hline No. & Nama Parasit & Prevalensi (\%) \\
\hline 1 & Dactyrogilus $s p$ & 50 \\
2 & Gyrodactilus $s p$ & 20 \\
3 & Tricodina $s p$ & 60 \\
4 & Vorticella $s p$ & 20 \\
5 & Oodinium $s p$ & 10 \\
6 & Saprolegnia $s p$ & 30 \\
\hline
\end{tabular}

Sumber: Diolah dari Data Primer, Tahun 2017

Tabel 5 di atas terlihat bahwa Tricodina sp juga memiliki prevalensi yang tertinggi bahkan lebih tinggi dari lokasi I yaitu mencapai $60 \%$ yang berarti bahwa pada lokasi II $60 \%$ ikan sudah terinfeksi Tricodina, kemudian diikuti oleh Dactyrogilus sp 50\%, kemudian Saprolegnia sp 30\%, Gyrodactilus sp $20 \%$ dan vortycella sp $20 \%$ dan Oodinium sp 10\%. Masih sama dengan lokasi I sakitnya ikan nila akibat komplikasi berbagai jenis parasit bahkan beberapa jenis prevalensinya lebih tinggi dari lokasi, hanya gyrodactillus prevalensi justru lebih rendah, namun demikian bisa dipastikan kematian ikan nila di lokasi II adalah akibat kerjasama serangan keenam jenis parasit tersebut.

Di lokasi III (Tiga) yang merupakan kolam kontruksi beton prevalensi masing-masing jenis parasit dari enam parasit yang ditemukan ternyata jauh lebih tinggi dari lokasi I dan II, bahkan tricodina sp prevalensinya mencapai $80 \%$, dactyrogilus sp mencapai $70 \%$ demikian juga yang lainnya semuanya 
Diagnosa, Analisis dan Identifikasi Parasit yang Menyerang Ikan Nila (Oreochromis Niloticus) Pada Kawasan Budidaya Ikan Di Subak "Baru” Tabanan

meningkat. Adapun prevalensi masing-masing jenis tersebut seperti ditunjukkan pada Tabel 6 berikut:

Tabel 6

Prevalensi Jenis Parasit pada Lokasi III

\begin{tabular}{ccc}
\hline No. & Nama Parasit & Prevalensi (\%) \\
\hline 1 & Dactyrogilus $s p$ & 70 \\
2 & Gyrodactilus $s p$ & 30 \\
3 & Tricodina $s p$ & 80 \\
4 & Vorticella $s p$ & 30 \\
5 & Oodinium $s p$ & 20 \\
6 & Saprolegnia $s p$ & 50 \\
\hline
\end{tabular}

Sumber: Diolah dari Data Primer, Tahun 2017

Ketiga tabel di atas terlihat bahwa prevalensi serangan masing-masing jenis parasit pada lokasi III adalah yang paling parah, hal ini berbanding lurus dengan nilai dari faktor kondisi ikan di mana secara rata-rata pada lokasi tiga kondisi ikan nila adalah yang paling buruk, bahkan hampir tidak ada ikan nila yang termasuk katagori masih sehat, hal ini disebabkan oleh pada lokasi ini pergantian debit air di kolam sangat sedikit karena pada saat penelitian terjadi masalah pengairan di kawasan budidaya.

Menurut Zonneveld (1994) dalam Anonimus 2008b, menyatakan bahwa terdapat banyak faktor yang menentukan seekor ikan menjadi sakit. Penyakit merupakan ekspresi dari kompleks interaksi antara host -pathogen-environment. Banyak situasi pembudidayaan, environment maupun host mungkin merupakan faktor yang paling abnormal. Hal tersebut digambarkan melalui 3 lingkaran yang saling overlapping untuk memperlihatkan interaksi antara host, potential pathogen dan environment (lingkungan).

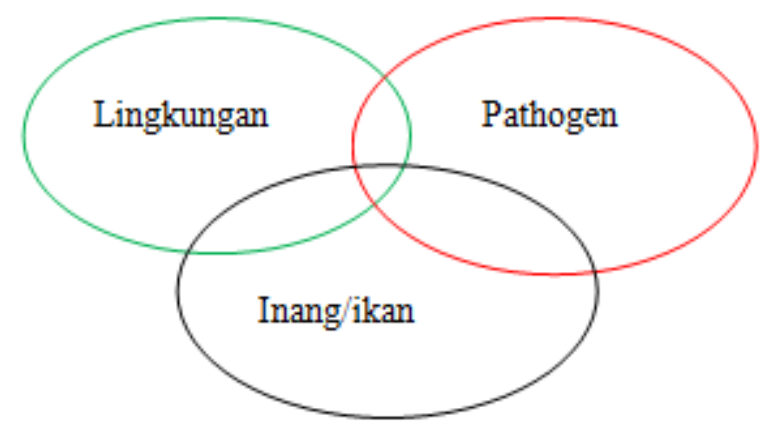

\subsection{Kualitas Air}

Beberapa parameter kualitas air yang diamati selama penelitian disajikan pada tabel. Pada Tabel 3.8 terlihat bahwa kualitas air relatif kurang baik, di mana oksigen terlarut sangat rendah apalagi untuk lingkungan dengan kepadatan ikan yang tinggi yang sebaiknya menurut Irianto (2005) kadar oksigen optimal antara 9-12 ppm, karbondiksida masih berada pada batas toleransi. Untuk pH. Hanya pada lokasi dua berada pada $\mathrm{pH}$ netral, sedangkan lokasi I dan III $\mathrm{pH}$ air cenderung asam dan ini berdampak tidak baik bagi ikan. Amoniak yang nilainya cukup tinggi mencapai $0.5-1 \mathrm{ppm}$ tergolong sudah sangat tinggi, di mana kelayakannya antar $0-0.05$ ppm hal ini sangat buruk untuk kondisi ikan dan justru akan mendukung berkembangnya parasit. Demikian juga Nitrit kadarnya juga tergolong sangat tinggi 0,5 1 ppm maka nitrit juga akhirnya mendukung penurunan kondisi ikan dan memicu berkembangnya parasit dengan baik. 
Diagnosa, Analisis dan Identifikasi Parasit yang Menyerang Ikan Nila (Oreochromis Niloticus) Pada Kawasan Budidaya Ikan Di Subak "Baru” Tabanan

Tabel 7

Parameter Kualitas air

\begin{tabular}{ccccc}
\hline No. & Parameter Kualitas Air & Lokaasi & Lokasi & Lokasi \\
\hline 1 & I & II & III \\
2 & Suhu $\left({ }^{0} \mathrm{C}\right)$ & $25-27$ & $25-26$ & $25-26$ \\
3 & Oksige Terlarut $\left(\mathrm{O}_{2}\right)(\mathrm{ppm})$ & 6 & 6 & 6 \\
4 & Karbondioksida $\left(\mathrm{CO}_{2}\right)(\mathrm{ppm})$ & 5 & 5 & 5 \\
5 & $\mathrm{pH}$ & 6,5 & 7 & 6 \\
6 & Amoniak $\left(\mathrm{NH}_{3}\right)(\mathrm{ppm})$ & 0.5 & 0 & 1 \\
\hline
\end{tabular}

Sumber: Diolah dari Data Primer, Tahun 2017

\section{Kesimpulan}

Pada kasus serangan penyakit ikan nila pada kelompok budidaya ikan Nila "Mina Ayu", ikan menunjukkan gejala berupa kelainan fisik yaitu warna tubuh berubah menjadi hitam pekat, tubuh menjadi kurus bahkan banyak menjadi cacat yaitu tubuhnya bengkok, sisik banyak yang terlepas, tubuh borok, sirip geripis, insang menggumpal dan tutup insang seperti cembung atau ada juga yang malah menjadi cekung. Gerakan ikan menjadi sangat pasif dan lambat. Berenang tidak teratur dan cenderung berputar-putar atau berenangnya miring. Tidak respon terhadap makanan dan tidak peka terhadap kejutan. Faktor kondisi berbeda-beda pada ketiga lokasi pengamatan, dan yang paling buruk faktor kondisi ikan nila adalah pada lokasi pengamatan yang ke tiga. Faktor kondisi tidak berhubungan dengan ukuran ikan. Gejala yang ditunjukkan oleh ikan yang sakit adalah sama untuk semua ikan nila yang terserang pada tiga lokasi dengan ukuran ikan yang berbeda. Hasil analisis laboratorium ditemukan enam (6) jenis parasit yang menginfeksi ikan nila yaitu: Dactyloyrus sp, Gyrodactylus spp, Tricodina sp, Vortycella sp, Oodinium sp, dan jamur Saprolegnia sp. Parasit ini merata ditemukan pada ikan yang sakit, hanya prevalensinya yang berbeda-beda. Ukuran ikan tidak ada kaitannya dengan jenis parasitnya karena keenanm jenis parasit tersebut menginfeksi ikan dari berbagai ukuran.

\section{Referensi}

Afrianto, E. \& Liviawaty, E. (1992). Pengendalian Hama dan Penyakit Ikan. Kanisius. Yogjakarta. Hal. 22.

Anonimus (1993). Deskripsi Hama dan Penyakit Ikan Karantina Golongan Bakteri. Buku 2 Kerjasama Pusat Karantina Pertanian dan Fakultas Pertanian Jurusan Perikanan. Universitas Gajah Mada. Yogyakarta. Hal. 7 -12 .

Anonimus (2002). Penyakit Ikan Karantina Golongan Bakteri, Deskripsi singkat mengenai Aspek Biologis, Gejala Klinis, Penyebaran dan Dampak pada Ikan. Pusat Karantina Ikan. Departemen Kelautan dan Perikanan. Jakarta.

Anonimus (2003). Gejala Umum Penyakit Ikan, Pusat Karantina Ikan, Departemen Kelautan dan Perikanan, Jakarta.

Anonimus (2008). Makalah Hasil Pemantauan Hama Penyakit Ikan Karantina. Pusat Karantina Ikan Departemen Kelautan Perikanan. Denpasar.

Anonimus (2008b). Penyakit dan Pengendaliannya Pada Ikan Mas dan Ikan Nila http:// salmahgominut.blogspot.co.id /2008/01/penyakit-dan-pengendaliannya-pada-ikan.html.

Anonimus (2011). Parasit pada Ikan yang Mirip tapi Tidak Kembar (Zoothamnium, Epistylis dan Vorticella). http://alinbelajarnulis.blogspot.co.id/2011/02/mirip-tapi-tidak-kembar.html.

Handajani H., \& Samsundari S. (2005), Parasit dan Penyakit Ikan. Penerbit Universitas Muhamadiyah Malang. Malang. Hal. 201.

Irianto, A. (2005). Patologi Ikan Teleostei. Gajah Mada University Press. Jogjakarta. Hal. 255.

Kabata, Z. (1985). Parasites and Diseases of Fish Cultured in the Trofics. Taylor and Francis. London and Philadelphia. Hal. 318.

Zonneveld, N., Huisman, E.A. \& Boon, J.H. (1991). Prinsip-prinsip Budidaya Ikan. PT.Gramedia Pustaka Utama, Jakarta. 